\title{
Textual Tactics of Identification
}

\author{
MARY LOUISE GOMEZ
}

University of Wisconsin-Madison

JENNIFER C. STONE

University of Washington

\section{NiKOLA HOBBEL \\ Humboldt State University}

In this article we merge de Certeau's theory of strategies and tactics with more recent work on socially situated identities to investigate how youth in one eighth-grade reading class withstood and resisted identities of "being remedial." On the basis of observational and interview data collected during a year-long ethnographic study, we illustrate how students used various texts to participate in official school practices while subverting those practices. [youth, race, class, resistance, remediation]

Historically, the institution of schooling - through forces of discipline (Foucault 1977) - has imposed notions of what counts as "being literate" in U.S. classrooms. State and district policies, classroom pedagogies, and text selection privilege particular ways of being, knowing, acting, and using language while negating others. Indeed, these forces seek to homogenize the understandings of policy makers, administrators, teachers, and students toward language and learning. Such forces also work to maintain cultural and linguistic segregation as well as trajectories of achievement by individuals affiliated with particular groups. However, as we explore in this paper, such attempts are never final, but always contested and negotiated.

The tension between discipline and resistance has been a driving force in literacy studies over the past few decades. As Hull and Schultz (2002a, 2002b) claim, some of the most compelling work in literacy studies over the past 20 years has dealt with the "unofficial" and outof-school literacies of youth. This work has explored a range of literacy practices in family, community, and peer spaces outside of school (Cushman 1998; Heath 1983/1996; Hull and Schultz 2002b; Moll 1992; Moss 1994; Valdés 1996); literacy practices influenced by new technologies (Alvermann 2002a; Knobel 1999; Lankshear 1997); and literacy practices occurring in school, but beyond the scope of the official curriculum

Anthropology and Education Quarterly, Vol. 35, Issue 4, pp. 391-410, ISSN 0161-7761, electronic ISSN 1548-1492. (C) 2004 by the American Anthropological Association. All rights reserved. Please direct all requests for permission to photocopy or reproduce article content through the University of California Press's Rights and Permissions website, at http://www.ucpress.edu/journals/rights.htm. 
(Dyson 1997; Finders 1997). As these studies point out, literacy involves social practices that vary across contexts and are influenced by power relationships. These authors have contributed new understandings of youths' literate lives that often are ignored and devalued in academic settings.

Our work extends this line of inquiry, examining youths' literacy activities in a culturally diverse eighth-grade "remedial" reading class where students not only resisted the notions that they were "deficient," but actively negotiated how various pedagogies were practiced on them. As scholars in reading (Alvermann 2002b; Collins and Blot 2003) and special education (Coles 1987; McDermott 1996; McDermott and Varenne 1995) point out, identities such as "remedial reader" and "disabled student" are cultural constructions limiting students to certain ways of practicing literacy. Early in this investigation, we began to see how students were employing "tactical literacies," using non-schoolsanctioned forms of literacy as resources for resisting identities of being "remedial." As a result, we began to ask , (1) How do students use reading, writing, and media to resist becoming "disciplined" and "remedied" by school? (2) How might we use insights gained from analyzing students' tactical literacies to build what Lankshear and Knobel (2002) call a "pedagogy of tactics"?

\section{Toward a Theory of Textual Tactics of Identification}

Here, we set the stage for our theoretical and conceptual framework by showing how Ms. Smith, ${ }^{1}$ a white, middle-aged teacher, used writing workshop-characterized by recursive cycles of drafting, peer editing, and revising - to highlight technical and structural strengths and weaknesses in eighth-grade students' writing. In this example, she used a district-supported tool of assessment (called the Six Traits of Writing) to structure and support a mini-lesson (Atwell 1987) aimed at teaching students what is important to attend to when writing. The students resisted her instructional focus on the mechanical aspects of writing by responding to the powerful message of a student-authored text and relating this message to their own lives as a textual tactic of affiliation. They also employed tactics that make their school time more habitable by subverting pedagogical structures and approaches that implicitly told them they were remedial, just as Ms. Smith ignored their agency as writers and readers by consistently redirecting their attention to the technical and structural aspects of writing. We use this vignette to illustrate our theoretical framework of "textual tactics of identification" - ways in which students used texts to refashion their identities and to make school a more habitable place.

Ms. Smith chose to use Cherise's writing as a model to capitalize on the student's excitement about this piece and draw her into the class. In the past, Cherise had frequently come to class and been sent out because of 
foul language and "bad" behavior. However, by using her writing with the whole class, Ms. Smith hoped to help her become engaged in staying in the classroom.

After passing out copies of Cherise's story to the class, Ms. Smith projects it onto the large screen in the front of the room. The writing sample is a personal narrative about Cherise's brother's drug use and arrest. Ms. Smith asks Cherise what help she wanted from the class. At first, Cherise screws up her face and says she does not know. Ms. Smith draws on her earlier writing conference with Cherise and raises paragraphing, grammar, and word choice as points for editing. On the board, Ms. Smith scrawls the words "Paragraphing, Grammar, and Word Choice" and instructs the class to read with these qualities in mind. The students read the story silently, pausing at times to get updates or clarifications on the narrative. For example, one boy, Ricky, asked if Cherise's brother still did drugs.

Cherise responds, "He used to. I don't know now. He used to live in Oklahoma, and now he lives in Reno."

Ricky replies with, "My dad did drugs, too. My uncle's in jail." Other students listen in and nod with understanding.

"My uncle's in jail, too. He got six years," Cherise relates.

"My uncle got eight. My dad also went," says Ricky.

Ms. Smith did not respond to the conversation. Rather, she redirects the class to look at Cherise's paper. The lesson moves on to address Cherise's paragraphing and other aspects of her writing.

Several days later, the class returns to peer-editing Cherise's story. The students excitedly offer editing advice to Cherise, sometimes even yelling over each other. Ms. Smith finally raises her voice above the excitement, "We can't go on like this. No one is listening to each other. Cherise is shouting at me; you're having private conversations!" The class settles down and takes turns sharing opinions about whether a colon would be an effective punctuation mark in one sentence. After several other changes, another student, Jasmine, states, "Cherise, they're changing your whole story. They're saying that there's nothing right about it."

Cherise's head slumps to her desk. Dee, a boy sitting next to her, strokes her hair. Jasmine (to Ms. Smith) states, "It's the fact that you're changing her story so much, it's not the fact that we're not listening!" At this point, the bell rings and the students leave.

What happened as Ms. Smith led the class in peer-editing Cherise's writing? How did Cherise and her peers view Ms. Smith's pedagogy? How were both parties - teacher and students-frustrated in their efforts to communicate their intentions and hopes? How was the class's school-assigned identity of "being remedial" implicated in Ms. Smith's instruction and Cherise's dejection at its emphasis on form rather than the content of her work?

To address questions raised by this reading class, we develop a theory of what we call "textual tactics of identification" to understand how youth used reading, writing, and media to make the school institution liveable and resist the identity of "being remedial." We draw on two bodies of work, including de Certeau's (1984) theory of tactics and strategies and more current, socially situated theories of identity. By drawing these 
two perspectives together, we develop an agency-oriented understanding of students' in-school literacy activities.

De Certeau (1984) distinguishes between two social forces: production and consumption. Production is controlled through powerful institutions such as armies, cities, businesses, and schools as well as agents within these institutions such as bosses, CEOs, and sometimes teachers. As Lankshear and Knobel note, "They have the position and power to prescribe social orders and syntactical forms (discourses, timetables, procedures, the organization of space and things within it, etc.)" (2002:2). In other words, producers capitalize on the ability to control place for the maintenance and reproduction of power. Their control is leveraged through what de Certeau calls "strategies" - processes directed toward disciplining place and maintaining power. Strategies, then, involve the ways in which producers remain powerful.

In the above vignette, Ms. Smith acted primarily as a produceran agent of the school institution charged with enacting strategies and maintaining power. As a strategic agent, she aimed to enforce "good" writing through the language and practices of writing workshop as an instructional framework and the Six Traits of Writing as a complementary assessment system, both of which were sanctioned by Ms. Smith's school district. This was reinforced in the organization of the classroom: the physical space and the social practices she invoked both supported a carefully configured classroom structure. These district policies were accomplished in a number of ways-by giving each student a copy of Cherise's writing and projecting that writing on the overhead, orienting students' bodies and workspaces toward that projection, and by adding to Cherise's text (writing the words "paragraphing, grammar, and word choice" at the top of the overhead and making changes as students suggested them), evoking the established classroom practice of teacher-guided peer review, and drawing on the terminology of the Six Traits of Writing and writers' workshop. Each of these strategic moves contributed to the maintenance of power in Ms. Smith's classroom, and to a pedagogical focus that relegated her students to a "remedial" category. However, as illustrated in this example, strategy was limited by students' responses.

Whereas the vignette is replete with examples of strategy, it is likewise replete with examples of tactics-the ways in which "consumers" capitalize on time to "make do" and/or erode the power of producers. Unlike producers, who maintain power by controlling place, consumers capitalize on time. As de Certeau states, consumption "... is devious, it is dispersed, but it insinuates itself everywhere, silently and almost invisibly, because it does not manifest itself through its own products, but rather through its ways of using the products imposed by a dominant economic order" (1984:xiii). These ways of using tactics enable consumers to adapt the dominant power for their own interests and circumvent the interests of producers. As Lankshear and Knobel point out, there are really two kinds of uses or tactics present in de Certeau's work. As they state, 
One side [of tactics] is captured by his concept of "making do." This is the idea of employing makeshift creativity to get sufficient small wins to smooth out the habitat and make it more livable. It is about obtaining some satisfactions, pleasures, and "peace" that help to infuse meaning into everyday experiences and routines. This is the sustaining side of uses and tactics. The other side is captured in de Certeau's notions of resistance and of "putting one over on the established order on its home ground." This is a more active or, in some cases, activist, side of uses and tactics. It is about resisting, tackling, wearing away at Producer culture. [2002:4]

This point regarding the duality of tactics is elaborated by Buchanan's (1993) argument that tactics not only are deployed by consumers reacting to forces of production, but also by actively defining the limits of production. As Buchanan states, tactics are not only reactions or responses to something. Rather, tactics "define the limits of strategy, and inform its modes of operation in a fundamental sense, thus forcing the strategic to respond to the tactical. In other words, the tactical has an active element in its constitution as well as a reactive one" (1993:5). Tactics, then, are what Lankshear and Knobel refer to as sustaining/maintaining and resisting production, and what Buchanan frames as defining the limits of strategy and reacting to it.

On the first day of the peer editing, when Cherise resisted providing a specific structural focus for the activity and when Cherise, Ricky, and Dee talked about family members who were incarcerated, they accomplished the twin goals of tactics as clarified by Lankshear, Knobel, and Buchanan. The second day-when the students argued over what to do with Cherise's writing and when Jasmine warned Cherise that the class was changing her story-offers additional examples of how the young people in Ms. Smith's class acted tactically. On these two occasions, students both were making school more agreeable and actively subverting Ms. Smith's intended plan for their own purposes. They were not simply resisting Ms. Smith's strategies. Rather, they were engaged in the ongoing erosion and subversion of these strategies. At the very moment that they were participating in "doing school," they were simultaneously "undoing school."

Through such tactics, students refashioned their identities from being remedial to affiliating with other youth according to interests and experiences. According to Kondo, "Identity is not a fixed 'thing,' it is negotiated, open, shifting, ambiguous, the result of culturally available meanings and the open-ended, power-laden enactments of those meanings in everyday situations" (1990:24). Identity is unstable, can adapt to varied contexts, and can shift according to the groups to which one is allied at any time. Individuals can take up identities they value, reject those that are unwanted, or resist those imposed on them. Cherise, Ricky, and Dee were not only enrolled in a reading class. They implicitly were asked to take up the identities of "deficient" students. In turning to work on identity, we ask how employing tactics not only 
benefited students by making schooling more habitable, but also how employing tactics supported students in thinking about themselves in more positive ways - as youth who not only had problems, but also possibilities.

Gee (2001) claims that there are four ways to view identity (nature, institution, discourse, and affinity), two of which are relevant to this study. Institutional identity frames identity in terms of institutional positions. In school, the positions of teacher, gifted student, remedial student, principal, parent volunteer, and so on are authorized by the rules and traditions of school to think, act, and use language in particular ways. As Gee (2001) points out, these roles actively may be sought out, as in the role of a teacher, or passively accepted, as in the role of a remedial student. Affinity identity, in contrast, frames identity in terms of allegiance to "affinity groups." According to Beck (1994) and Gee (2001), affinity groups are temporary, globally distributed groups who converge around topics or causes, but often share little else in common. Whereas institutional identities are tied to roles and physical spaces, affinity identities move beyond these boundaries. Thus, a "remedial student" also may be a fan of hip-hop music, who communicates via reading and writing with other fans around the world.

In this analysis of an eighth-grade classroom, such views of identity allow us to complicate and extend de Certeau's theory of strategy and tactics. The lens of institutional identity restricts individuals in the roles of teacher and students to a range of recognizable actions, textual practices, and ways of being and thinking. Ms. Smith and her colleagues expected students to take up the discourses sanctioned by the Six Traits of Writing, apply procedures identified by the Six Traits as significant for their compositions, and improve their writing along lines suggested by their teachers, peers, and the assessment tool they valued. Talking about imprisoned relatives lay outside of these institutional expectations; these students were viewed as violating strategic norms. Within the institution of school, the roles of administrators, teachers, and "good" students are oriented toward maintaining that institution. In contrast, affinity identities often operate beyond the scope of control of institutions and at times are tactical. Such affinity identities can be seen when Cherise and her peers coalesced as a group around their male relatives' arrests and jailing. By engaging in conversation about this topic, the students identified themselves in a way that was unrecognizable by Ms. Smith, whose response was to redirect the conversation to conventions and word choice.

As Gee (2001) points out, recognition is a key aspect in understanding identity. De Certeau's work complicates the notion of recognition by claiming that some of the most consequential tactical maneuvers remain unrecognized by institutions, although they may be recognized in other arenas such as affinity groups. As we found in literacy classroom activities, students often participated in official, strategic literacy events led by Ms. Smith, but they also behaved in tactical ways that drew on 
their affinity group memberships. In so doing, they subverted the goals of the literacy curriculum.

Through these textual tactics of identification, the youth in this study both affiliated with particular ways of being, often extending far beyond the realm of schooling, and they made do within and resisted the strategic forces at play in the classroom. By using a variety of texts-their own writing, published books and magazines, and popular media-youth made do within and resisted the remedial space of their classroom. Simultaneously, they created and maintained affinity group affiliations as ways to resist the imposed institutional identities that they were expected to adopt. As this theory allows us to see, these textual tactics of identification were not simple matters of resistance. Rather, the youth in Ms. Smith's class engaged in moment-by-moment negotiations between official and unofficial textual practices as well as institutional and affinity identities. Such a theory allows us to see the complexity of young people "being remediated" and "making do" through social practice.

\section{Method}

\section{Participants and Context}

This study took place in Woodhaven Middle School in Metropolis, a small, Midwestern U.S. city. Enrolling 587 students, 48.9 percent of whom were students of color and 41.7 percent of whom met federal income guidelines to qualify for free and reduced-price lunch, the school was located in an affluent neighborhood from which it drew part of its student body. The remaining students were bused to the school from low-income neighborhoods. From August 2001 to June 2002, we conducted research in one eighth-grade remedial reading class that enrolled 18 students, 15 males and 3 females: 6 whites, 9 African Americans, and 3 Latinos/Latinas. All but one qualified for free or reduced-price lunches, acknowledging their families as falling below federal poverty benchmarks.

We were interested in how teachers mobilize marginalized youths' participation in literacy activities in school. Sandra Smith, a white, middle-class teacher with many years of middle school teaching experience, agreed to join our project. One of us had met Ms. Smith several years earlier as part of a staff development project; another had met her as a supervisor of a nearby university's student teaching program, which located student teachers in Ms. Smith's middle school. These relationships supported our development of cordial, professional relationships with her. Ms. Smith told us she had a challenging group of students in her remedial reading class the prior year and anticipated that she would have another such group in the coming year. She said that her students were angry because they were required to take (English) reading rather than a foreign language (as their middle school peers could elect to do), and also felt that the class implicitly named them as remedial. 
To investigate what was happening in this class and why it might be occurring, our project employed three researchers who worked in planning, data collection, data analysis, and writing. Each of us had previously participated in teaching or research projects with children or youth deemed remedial or seen as needing special help to complete "regular" schoolwork. We were empathetic with Ms. Smith and intrigued to view her teaching and students' learning - to understand how, in the face of pressure from peers, school district, state, and federal policies, a class labeled remedial would proceed.

\section{Data Collection}

During the school year, we conducted nearly 300 hours of observations both in and out of class, including the lunchroom, hallways, and playground. These sites provided a multifaceted view of how Ms. Smith's class fit into the rest of the school. Observations were documented in field notes, which were typed and returned weekly to Ms. Smith for her reading and feedback. During these observations, we attended to students' interactions with one another and adults in and out of class, reading and writing practices in the class, and moments where students' lives supported or came into conflict with schooling.

Using semistructured protocols, Ms. Smith was interviewed three times over the school year. We interviewed students in small focus groups about what they were learning and salient events inside and outside of Ms. Smith's class. Each student was interviewed individually once. Students seemed interested in us as "outsiders," were cooperative with our requests for interviews, and seemed pleased to have their viewpoints noted. We also collected artifacts from Ms. Smith's class, including copies of students' reading logs and writing samples.

\section{Data Analysis}

Data were analyzed through a recursive process (Strauss and Corbin 1990) in which field notes and interview transcripts were read on multiple occasions. Categories were formed and reformed dialogically with our emerging theoretical understandings of the class. Major themes that we initially identified included the construction of "remedial reading," teacher frustration with student behavior and students' continual resistance to school, and tension between officially sanctioned literacy practices and students' interests and needs. Later, we refined these themes with our theoretical understandings of tactics and identity and used them to develop the theoretical lens of textual tactics of identification to account for what we saw in Ms. Smith's classroom. We "tested" our developing framework by looking for confirming and disconfirming evidence of instances where students engaged in reading, writing, or media representations in tactical ways. Likewise, we looked for instances where Ms. Smith could be said to operate strategically and where she 
seemed not to do so. We verified our findings in our formal interviews and informal discussions with Ms. Smith and her students.

\section{Findings}

\section{Students' Understandings of Strategies}

Strategies played out in Ms. Smith's reading class at a number of levels. First, at a broad level, the school as an institution-including disciplinary policies, placement practices, tracking, and the distribution of resources-played a major role in determining who enrolled in the class, who succeeded and failed in it, and what counted as reading. Also, curricular mandates and materials played a central strategic role. These included state and district standards, texts for students provided through the class and school library, and the Accelerated Reader (a structured program in which youth read from predetermined book sets and answer simple comprehension questions following reading) used in the communication arts classes, which Ms. Smith's class was intended to support. Finally, many of Ms. Smith's classroom practices also were strategic. These included use of duolog entries (a dual record journal in which students wrote both summative and interpretive comments following reading), and silent reading, her participation in behavior referrals and suspensions, and her drawing on nearby university and school district professional development activities. Each of these layers of production framed what texts, behaviors, and language practices were valued in Ms. Smith's classroom.

The students in Ms. Smith's classroom were well aware of many of the strategies at play in their institutional context, although they often seemed unaware of how to challenge those forces. In the following excerpt from a group interview with several students of diverse racial/ethnic and language backgrounds, they detail the placement procedures that determined they would take the remedial reading class rather than a foreign language.

Interviewer: So, why are you in the reading class?

Amber: Well, I got into the reading class because Spanish was not going very good. I couldn't like...

Mike: $\quad$ Read Spanish.

A: $\quad$ Yeah, it was really hard for me to read Spanish. So they took me out and transferred me into the reading class, and it's, like a lot better.

I: $\quad$ You didn't enjoy Spanish?

A: $\quad$ No.

I: $\quad$ Do you think you might try a foreign language later?

A: $\quad$ No, probably not. Not this year.

(The students banter about the languages they speak and then get back to the interview topic. Mike volunteers to tell the story of why he is in the reading class.) 
M: It goes like this, it goes like this. Okay, I was made...

I: $\quad$ I was made?

M: $\quad$ I had to be in this class. I didn't pick no foreign language.

I: $\quad$ You didn't pick any foreign language? Wait a minute, you ...

José: Sometimes they just put you in there for no reason.

I: So, you decide you don't want to take a foreign language, which is what you're saying?

M: No, I wanted to take a foreign language, but I didn't know about, you know, Spanish, but I'm going to be taking Spanish next year, so...

A: $\quad$ Yeah, so am I.

(The students talk about the languages they plan to take next year in high school.)

I: Why aren't you taking Spanish, José? Would it be too easy for you?

J: No, because I was put, okay, in this class last year. Because I was in ESL [English-as-second-language] class. I was too good for it [ESL], so they just switched me to reading.

M: $\quad$ Yeah, you were in reading with me last year...

I: $\quad$ And why are you in reading, Ivan?

Ivan: I was in Spanish and they forced me to take reading.

I: What?

IV: Uh-huh.

M: $\quad$ He wasn't good at Spanish.

I: $\quad$ You weren't good at it?

M: He sucked!

IV: No, I wasn't good at reading [Spanish or English], so I had to take reading.

This interview excerpt demonstrates one of the key strategic forces in Ms. Smith's class, placement and tracking procedures. As the students pointed out, they were placed in this class for a number of reasons, including difficulty learning spoken or written Spanish, behavior viewed as delinquent, and not knowing about the institutional mechanisms for getting into Spanish. Amber said she was enrolled in Spanish, but when she did not do "very good" and had difficulty reading Spanish, she was instead placed in a class emphasizing reading in English. Likewise, Ivan asserted that he "wasn't good at" reading Spanish or English, and was removed from studying Spanish and placed instead in the reading class. Here, Ivan sounded much like José when he stated that unspecified authorities "forced me to take reading." Mike also said he was "made" to enroll in the reading class as he claimed not to have known the possibility for foreign language enrollment. José said that "Sometimes they put you there for no reason" and that he was "too good for ESL" and was "switched" to reading. This seemed erratic to José and carried out by unknown but powerful people. Further, his transfer from ESL classes to one in reading in seventh grade predetermined his continued placement in reading for eighth grade, and ultimately his placement in lower-level foreign language and English classes in high school. Ironically, like José, many of the students were adept at other languages, yet they were not 
encouraged or allowed to pursue these. All of the students evidenced feelings that they were "forced" to enroll in the reading course by people they did not know but who had authority in the school. As José and his classmates reported, being placed in a remedial reading course made them unhappy - they were labeled as remedial when they did not believe themselves to be remedial.

Strategic practices such as tracking framed the local and global backdrop for students' textual tactics of identification. Next, we turn to three examples of pedagogy that show how students were positioned by producers-the school, teachers, and administrators-and how students responded as tacticians. These examples focus on writing, reading, and media.

\section{Tactical Writing}

We return to the vignette presented earlier in the article with Ms. Smith leading the peer editing of Cherise's writing. When interviewed, Cherise said that she had always "been pretty good at writing, except that I need more creative words." Cherise reported she not only wrote at school when assigned writing projects, but also frequently wrote stories at home. She said, "I write lots of stories... at home I've got a computer, so I write stories.... I like to write a lot. When I get started writing something, I can't stop." However, she recognized that she had some technical and mechanical problems in her writing: "I don't even know how to separate a paragraph from another paragraph." She also said that she would like her writing to "flow together, my stories are all jumpy and everything." Ironically, what Cherise recognized she needed help with-such skills as paragraphing and word choiceand what Ms. Smith called attention to, were the same dimensions of writing-noted as significant by the district-adopted Six Traits of Writing assessment. However, what Cherise told us she most sought from having her writing displayed for the class was for Ms. Smith and her classmates to see how much time and effort she put into it.

Ms. Smith raised elements from the Six Traits-word choice, voice, convention, ideas, sentence fluency, and organization-to discuss students' texts; however, she rarely addressed the often heartrending and sensational content of their writing. Following the teacher's strategic guidance, many of the students engaged in these official literacy practices by offering sanctioned feedback to their peers. Simultaneously, a number of students strayed from the agenda set by Ms. Smith and shared stories about their families that often had tragic outcomes. In so doing, students were affiliating around particular life circumstances, as well as resisting the institutional constraints of writers' workshop. Through writing these stories and responding to them outside of the official discourse of Six Traits, students were engaged in textual tactics of identification. 
This vignette demonstrates Ms. Smith's role as a producer and her interest in students complying with the rules of production-in this case, the ability to produce multi-paragraph essays with clear topic sentences and appropriate argumentation. Ms. Smith often claimed that she felt pressed to redirect attention from topics in which students were interested to instead address the form and technical aspects of writing. She acknowledged that in the highly competitive high school that the students would attend, technical perfection, not life experiences, mattered. In an interview conducted early in the school year, Ms. Smith bemoaned the lack of attention her students gave to her pedagogy:

We can only hope that the more they read, the more they pay attention, the more they pick up on, and are able to follow through with in reading and thinking as we read. That's why when they come in I expect behavior that says, "I'm a student" and "I'm about learning." .. [They say] "I'm not paying attention in life-nor in this classroom, nor in this school. I'm just fooling around, having a great old time." And then we get to ninth grade and we have a 20 percent dropout rate at Exeter High School by Christmas.

Ms. Smith was empathetic with her students' dilemmas, but she also was conscious of numerous technical imperfections in their writing, all of which she saw as pointing them in the direction of low grades and placements in ninth grade, and, perhaps eventually, to dropping out of school. However, the students understood Ms. Smith's avoidance of the content of their writing as reflecting a lack of engagement with them as people. This can be seen in students' insistence on sharing personal stories, and in Jasmine's claim that Ms. Smith's changing of Cherise's story was the problem, not their behavior. The students were interested in expressing their commonalities with one another and used this opportunity to affiliate and identify with the text through their stories. This required working against Ms. Smith's intentions of creating technically and structurally acceptable writing. As Jasmine's claims pointed out, the students saw these grammatical changes as changing what Cherise intended her audience to hear.

Through such affiliative moves, the students also more broadly resisted their placement in a "deficient" reading class and claimed value as a group. Cherise recognized she had some structural problems in her writing, but she liked to write and sought Ms. Smith's validation of her interest. By reducing Cherise's story to its form, Ms. Smith renamed the writing as deficient and brought the remedial nature of the class to the forefront. Thus, the students' textual tactics of identification were responding not only to the local conditions of this event, but also to the systemic, institutionalized practices of sorting students and fixing the writing of those viewed as remedial. 


\section{Tactical Reading}

Ms. Smith said her colleagues claimed that her job in the reading class was to provide students with extended reading opportunities and, in so doing, to support the Accelerated Reader curriculum. For the Accelerated Reader program, students were expected to select a book from a sanctioned list, read it, and take a computerized comprehension test for which they earned points toward a number of rewards. However, as Ms. Smith expressed on several occasions, she felt caught between the pull for students to read officially sanctioned texts and her students' interests and needs. Whereas she saw the value of supporting students' achievement in communication arts, she also knew that students needed to have opportunities to self-select high interest materials for reading. In an interview, she spoke of her frustration about encouraging students to read books they had selected.

I want them to go deeper into what we've already read, or preferably to bring something they're reading. Because to get them to bring what they're reading to class is very difficult. For the most part, they don't want to do that; for whatever the variety of reasons exist, the bottom line is they won't bring their own reading material.... When I would say to them, bring your own book to class, only one or two would bring their own book.

Students chose to read a range of official and unofficial texts in Ms. Smith's class. They frequently pushed the limits of what counted as reading material in her class, often using tactical texts to identify with peer groups rather than with school.

For example, one student, Ricky, an African American, often chose to read Captain Underpants books, a series about a superhero's adventures. These books were far below his reading level, yet Ricky read and reread them throughout the school year. Like most of his independent reading selections over the school year, including Spiegelman's Maus: A Survivor's Tale (1997), a graphic novel of the Holocaust, Captain Underpants contains graphic illustrations. In addition to including humor and content congruous with interests of youth culture, Captain Underpants also included an African American character and references to contemporary African American culture. Furthermore, in selecting Maus: A Survivor's Tale, Ricky chose a text with a genre that pushed the limits of school literacy, but the content of which was congruous with the Holocaust. In reading these books, Ricky was using school ways of being to subvert the practices associated with schooling.

Ricky also engaged in another example of tactical reading-magazine reading. Indeed, many of the students in the class read magazines during reading time, including Transworld Skateboarding, Black Beat, and Teen Cosmo. Through these texts, students identified themselves as certain kinds of people, engaging in learning and participating in the particular language practices associated with those affinity groups. The following 
excerpt demonstrates an example of the frequent struggle about reading material in Ms. Smith's class.

In her usual routine, Ms. Smith takes the status of the class at the beginning of reading time. Teachers on her team recently have asked that students read "real" literature during reading time-following the Accelerated Reader program, so today Ms. Smith is particularly adamant about students reading appropriate materials. Ms. Smith moves about the class with her notebook, recording what students are reading and on what pages they currently are working. When she gets to Ricky, he insists that he will read his EastBay magazine, a discount sports apparel catalog.

Ms. Smith: I don't know if that's going to serve you well in your other classes and in the future.

Ricky: My mom knows I'm reading it [the EastBay magazine-format catalog]—she bought it for me.

MS: $\quad$ Well, ask your parents if they want you reading a book or a magazine in school-to increase your reading level.

R: $\quad$ (walking up to Ms. Smith) This magazine has hard words in here. Look! (He points to an article and holds it up for her to see.)

Having proved his point, Ricky, smiling, quietly returns to his desk. The next student on the list, Robert, tells Ms. Smith he doesn't like his book and wants to read Ricky's magazine. Ms. Smith gives him "the look" and he grabs SCOPE (a high interest, easy-to-read magazine designed for schools), and quietly whispers to his friend Antonio when Ms. Smith is not looking.

This scene demonstrates a number of ways in which Ricky and other students resisted officially sanctioned books and engaged in textual tactics of identification. Perhaps most obviously, students did so by reading other materials that were representative of their shared affinities and more responsive to their ethnic/cultural identities than the texts sanctioned by the school curriculum. The students knew that Ms. Smith preferred them to read something rather than nothing at all, so they frequently chose to read anything but sanctioned books. Ricky also used his family institution to support his desire to read a magazine that opposed the school institution. He used the presence of difficult vocabulary, a feature valued by producers, as a rationale for reading a magazine. Not only did these literacy practices resist the goals of Ms. Smith and the school institution, but, through their choice of these magazines, students identified themselves as certain kinds of people affiliated with particular groups. Ricky read the catalog to show his fashion sense as a young African American male associated with sports and hip-hop culture. Robert also identified with Ricky and this group through his attempt to read the magazine.

When interviewed, Ricky reported that the reading class was helping him because "when you read I used to go straight through and I wouldn't stop at a period. And so, I learned to stop at a period and stuff 
like that." He could not tell much more than that about how the class had benefited him. He also said that his handwriting had improved, as he had been "sloppy." With regard for what and how he read, Ricky said, "When I read books, I can finish the whole thing, but most of the time, I'll just skip that book, and go on to another one, like, when I'm halfway done, and I'll just skip it." Here, Ricky acknowledged changes in his reading and writing practices due to the course; however, they were technical, surface-level changes. Ricky heard the message that his school was sending - technical and structural changes are important. He found ways to affirm that he had made some of these changes: He attended to the punctuation marks in his reading, his handwriting was readable, and he could finish "whole" books. In these ways, Ricky made what Lankshear and Knobel (2002) call a "small win" to make the institution more habitable through the kind of reading he did outside of schoolmagazines that showcased his interest in fashion, sports, and hip-hop culture. Thus, he both sustained the most modest goals of the institution and "put one over on it" as he rarely finished a book, although he claimed he could do so, and attended to structural-level changes in his reading - but only to the extent that he stopped at rather than ignored such punctuation marks as periods.

\section{Tactical Media}

As Dyson (1997) points out, youth often infuse school-based talk and writing with media and popular culture references. One student, Dee, an African American male, often drew his sports and music interests into official and unofficial language events. Like many of his peers, Dee used media and popular culture to affiliate with particular student groups and to resist school culture. Indeed, he was adept at artfully style-shifting between popular language forms to an exaggerated hypercorrect voice reflecting white teachers' voices. Ms. Smith usually greeted these moments with either reprimands or with silence. For example, one day Dee entered rapping "Saturday (Oooh! Oooh!)," a track from the Word of Mouf album by Ludacris, an Atlanta-based hip-hop artist known for his "tight" rhythms and outrageous lyrics.

After a few minutes Ms. Smith interrupts him, saying, "Dee, you are disturbing...."

"... the Peace?" Dee finishes for her, smiling playfully.

Ms. Smith looks at him with warning, "Yes."

"Well" Dee replies, "Dominic started talking to me, and I started talking to him, the conversation went on..."

Ms. Smith looks at him, and Dee picks up his book and goes over to sit next to her. He reads intently, like a perfect student, until the end of the reading time.

Dee frequently sang popular songs that Ms. Smith and other teachers had not heard. As exemplified above, Dee enjoyed playfully moving 
between singing these and acting like a model student. Through these textual tactics, Dee actively resisted and undermined Ms. Smith's authority, doubly so because he also took on seemingly strategic language practices and behaviors. He also aligned himself with many other students in class who were familiar with this music and more broadly affiliated with hip-hop culture.

Although Ms. Smith saw the potential for drawing on Dee's artfulness and language abilities - for example, one day she had Dee lead the class, and he used his ability to style-shift very effectively-she often was at a loss for how to do so. She was not familiar with groups such as Ludacris or the hip-hop movement, and was unable to recruit this aspect of popular culture in her teaching. In this way, Dee used the song not only to affiliate with students like him, but to do so in opposition to teachers and school.

\section{Implications}

The theoretical lens of textual tactics of identification developed in this article extends work on literacy and identity in key ways. First our work develops an agent-centered approach to understanding how and why students use texts. This frames students' text usage from their points of view rather than from an institutional point of view as active meaning-makers in the world. This work also highlights the importance of looking at intersections between "official" and "unofficial" spaces in schools. De Certeau's theory of tactics is particularly well suited for this purpose, as it offers a perspective from which to understand how students are making do, pushing back, and reflecting on schools as institutions. Although de Certeau's theory previously has been taken up in literacy studies (Lankshear and Knobel 2002), our study offers an account of how tactics play out in the lives and literacy practices of students and teachers. Likewise, by placing the concept of tactics in dialogue with identification, we extend rather than merely illustrate de Certeau's work. This theoretical move points to the importance of affiliations that students engage in when creating and using texts. Indeed, it raises the claim that tactics are not just individual acts; rather, it demonstrates how they are social.

As a group, students in Ms. Smith's class remained unconvinced they were placed there because they were deficient. They named unspecified "authorities" as responsible for their placement and contested the reasoning that resulted in their placement in the class. Like Willis's (1981) lads, Ms. Smith's students saw that they could construct another way of being in school that they could collaboratively understand and explore. Students saw how they could not only resist the imposition of remedial identities and engage in sustaining affinity identities, while co-constructing moment-by-moment practice with their peers and teacher. In so doing, they participated in and moved beyond the official, sanctioned curriculum. 
When students read books such as Captain Underpants or magazines such as Black Beat or Teen Cosmo, they were valuing the music, clothing, humor, and ways of interacting that youth of their socioeconomic, language, and "race" / ethnic background appreciated. When they shared stories of incarcerated relatives, they bonded around the shared experiences that their writing referenced. When they brought hip-hop music and references to sports into class, they built alternate affiliations to the remedial identities offered to them. Unlike Willis's lads, Ms. Smith's students viewed their school futures as bright: They would enroll in foreign languages in high school; they could achieve and move past their assigned institutional identities as remedial. We hope that their youthful optimism will be met by teachers who also will see the dreams and possibilities that Cherise, Ricky, Dee, and students like them hold.

We often see teachers aiming their pedagogy at "fixing" students, requiring individual accountability for their bodies, behavior, selection of texts, and written products. This is carried through and reinforced by deficit-oriented evaluation practices. We suggest that a more worthy and productive project would be to acknowledge students' literacy resources and scaffold their command of powerful forms of language. In this way, students could achieve structural competence in their literate activities. Further, they could produce and circulate powerful ideas to one another and the adults who care about them. Toward these ends, we propose a theoretical stance that explicitly engages in identifying the ways in which students use texts to subvert and resist the discipline of school and the identity of being remedial.

This analysis also points to the need to develop a "pedagogy of tactics" (Lankshear and Knobel 2002). We argue that teachers need to attend to the ways in which students can use reading, writing, and media to powerfully critique dominant discourses. This is particularly important in so-called remedial reading classes, where curriculum is often stripped down to the basics. We propose, instead, that such classes-which often serve students from disenfranchised groups-pay explicit attention to the ways that literacy can be used to subvert discipline. For example, when Ms. Smith asked the class to focus on the structural features of Cherise's writing, she was implicitly requesting they not attend to Cherise's pain and worry over her brother's drug rehabilitation therapy and its consequences for her family's well-being. What could Ms. Smith have done differently? If she had asked students to respond to Cherise's story first as a way of effectively communicating her ideas, and then to focus on how they were communicated, the class would have been more engaged. We believe that Ms. Smith understood that improving writing is not only about substituting one word for another, or breaking a piece into paragraphs; rather it is a matter of helping students make more powerful and profound choices in their writing. What she could not seem to mobilize in her pedagogy during our observations was the notion that to reach youth who feel rejected and diminished by schools we need both to intrigue them and validate their ideas, and insist on 
high-quality academic writing, and show students how such writing can be crafted.

It is important to recognize, however, that Ms. Smith and other teachers do not necessarily apply these pedagogical practices and assessments to students of their own personal accord. Rather, they enact institutional roles and forces that press against them in the same way those forces press against students. Just as Ms. Smith required her students to choose particular reading and writing materials, make certain kinds of entries regarding the books they were reading, and write in certain valued forms, so too did her colleagues monitor her for offering particular curricula, instruction, and assessments. Ms. Smith simultaneously embodied the role of producer and consumer. She was expected to maintain an orderly class, engage youth in reading pre-selected books, and master the art of the "five-paragraph" theme (an essay form frequently taught in schools). The school also expected that students improve their reading and writing skills.

Our work offers a critique of current curriculum, instruction, and assessments that narrowly construe reading and writing. We argue that teachers also can take on the role of tactician, both "getting by" and resisting these institutional pressures. They can use particular curricula, instruction, and assessments to show students how the system values certain writing features. Likewise, teachers can show youth how institutionally valued forms of reading and writing can be used and transformed for powerful purposes. For example, Ms. Smith geared the conversation about Cherise's writing to the Six Traits of Writing assessment, recently adopted by the school district. The goal of her lesson was to address, through Cherise's writing, traits of word choice and conventions. However, student writing is much more complex than such assessments allow. By reducing Cherise's writing to its structural features, Ms. Smith missed the point of such writing and the potentially powerful dialogue that could come out of it.

In conclusion, in a climate in which students of color, English language learners, and students from lower socioeconomic backgrounds are being failed by our schools at alarming rates, we must rethink how we teach reading and writing, respond to students, and theorize their literate activities. Revision of how we think and act holds powerful possibilities for the future of our communities and institutions such as schools. Theorizing about literacy and building pedagogy based on a theory of textual tactics of identification offers a place to begin this project.

Mary Louise Gomez is professor of curriculum and instruction at the University of Wisconsin-Madison, where she chairs the Literacy Studies Area (mlgomez@ education.wisc.edu). Jennifer Stone is assistant professor of language, literacy, and culture at the University of Washington (jcstone@u.washington.edu). Nikola Hobbel is assistant professor of English at Humboldt State University (hobbel@humboldt.edu). 


\section{Notes}

Acknowledgments. The authors thank University of Wisconsin-Madison colleagues Rebecca Black, Amy Suzanne Johnson, James Paul Gee, and Beth Graue for helpful comments on the manuscript, and editor Teresa McCarty for her excellent critiques. This project is part of the Center on English Learning and Achievement (CELA), which was supported by the U.S. Department of Education's Office of Educational Research and Improvement (now the Institute of Education Sciences; OERI award number R305A60005). The views expressed here do not necessarily represent the positions or policies of the sponsoring agencies.

1. The names of the teacher, students, community, and school are pseudonyms.

\section{References Cited}

Alvermann, Donna

2002a Adolescents and Literacies in a Digital World. New York: Peter Lang.

2002b Reading Adolescents' Reading Identities: Looking Back to See Ahead. Journal of Adolescent and Adult Literacy 44(8):676-690.

Atwell, Nancie

1987 In the Middle. Writing, Reading, and Learning with Adolescents. Portsmouth, NH: Boynton Cook.

Beck, Ulrich 1994 Ecological Politics in an Age of Risk. Cambridge: Polity.

Buchanan, Ian

1993 Extraordinary Spaces in Ordinary Places: de Certeau and the Space of Postcolonialism. SPAN 36. Electronic document, http://wwwmcc. murdoch.edu.au/ReadingRoom/listserv/SPAN/36/Jabba.html, accessed August 16, 2002.

2000 Michel de Certeau: Cultural Theorist. London: Sage.

Coles, Gerald

1987 The Learning Mystique: A Critical Look at "Learning Disabilities."

New York: Pantheon Books.

Collins, James, and Richard Blot

2003 Literacy and Literacies: Texts, Power, and Identity. Cambridge, UK:

Cambridge University Press.

Cushman, Ellen

1998 The Struggle and the Tools: Oral and Literate Strategies in an Inner

City Community. Albany: State University of New York Press.

de Certeau, Michel

1984 The Practice of Everyday Life. Steven Rendall, trans. Berkeley: University of California Press.

Dyson, Ann Haas

1997 Writing Superheroes: Contemporary Childhood, Popular Culture, and Classroom Literacy. New York: Teachers College Press.

Finders, Margaret

1997 Just Girls: Hidden Literacies and Life in Junior High. New York: Teachers College Press.

Foucault, Michel

1977 Discipline and Punish: The Birth of the Prison. Alan Sheridan, trans. (Reprint ed.). New York: Vintage Books. 
Gee, James Paul

2001 Identity as an Analytic Lens for Research in Education. Review of Research in Education 25:99-125.

Heath, Shirley Brice

1983 [1996] Ways with Words: Language, Life, and Work in Communities and Classrooms. New York: Cambridge University Press.

Hull, Glynda, and Katherine Schultz

2002a Literacy and Learning out of School: A Review of Theory and Research. Review of Educational Research 71(4):575-611.

2002b Negotiating the Boundaries between School and Non-School Literacies. In School's out: Bridging out of School Literacies with Classroom Practice. Glynda Hull and Katherine Schultz, eds. Pp. 1-10. New York: Teachers College Press.

Knobel, Michelle

1999 Everyday Literacies: Students, Discourse, and Social Practice. New York: Peter Lang.

Kondo, Dorinne

1990 Crafting Selves: Power, Gender, and Discourses of Identity in a Japanese Workplace. Chicago: University of Chicago Press.

Lankshear, Colin

1997 Changing Literacies. London: Open University Press.

Lankshear, Colin, and Michelle Knobel

2002 Steps toward a Pedagogy of Tactics. Paper presented at the National Council of Teachers of English Assembly for Research Mid-Winter Conference, New York (February).

McDermott, Ray

1996 The Acquisition of a Child by a Learning Disability. In Understanding Practice. S. Seth Chaiklin and Jean Lave, eds. Pp. 269-305. Cambridge, UK: Cambridge University Press.

McDermott, Ray, and Hervé Varenne

1995 Culture as Disability. Anthropology and Education Quarterly 26(3):324-348.

Moll, Luis

1992 Funds of Knowledge for Teaching: Using a Qualitative Approach to

Connect Home and Classrooms. Theory into Practice 31(2):132-141.

Moss, Beverly

1994 Literacy across Communities. Cresskill, NJ: Hampton Press.

Spiegelman, Art

1997 Maus: A Survivor's Tale. New York: Pantheon Books.

Strauss, Anselm, and Juliet Corbin

1990 Basics of Qualitative Research: Grounded Theory Procedures and Techniques. Newbury Park, CA: Sage.

Valdés, Guadalupe

1996 Con Respeto: Bridging the Gap between Culturally Diverse Families and Schools: An Ethnographic Portrait. New York: Teachers College Press.

Willis, Paul

1981 Learning to Labour. How Working Class Kids Get Working Class Jobs. New York: Columbia University Press. 